\title{
Marine fisheries and mariculture in Croatia: Economic and trade analysis
}

\author{
Federica De Leo a*, Pier Paolo Miglietta b, Slađana Pavlinović c \\ a Department of Management, Economics, Mathematics and Statistics, University of Salento, Italy. \\ ${ }^{\mathrm{b}}$ Faculty of Economics, Libera Università Mediterranea - Jean Monnet, Italy. \\ c University of Split, Faculty of Economics, Croatia \\ ${ }^{*}$ Corresponding author's e-mail: federica.deleo@unisalento.it
}

H I G H L I G H T S:

1. More fish products are exported from Croatia to Italy than imported from Italy to Croatia.

2. Average size of Croatian fishing fleet vessel is much lower than the average fishing vessel size arriving to Croatian ports.

3. Small capacities of Croatian fishing fleet indicate that creation of additional value is needed along the fish market trade network.

\section{Article History}

Received: 13-09-2014

Revised Received: 30-10-2014

Accepted: 22-11-2014

Available online: 26-11-2014

Keywords:

Capital accumulation;

Economic growth;

Institutional reform;

Technological innovation.

JEL Classification:

D24; D46; 043; 047.

(C) 2014 The Authors. This is an open access article under the terms of the Creative Commons Attribution License 4.0, which allows use, distribution and reproduction in any medium, provided the original work is properly cited.

\subsection{Introduction}

Fishery activities represent an important segment of Croatian economy since they are mostly export oriented. Furthermore, among Croatian agriculture products, export of tune takes very high fifth place (EUMOFA, 2013). Although, the estimated share of the fishery in GDP varies from $0.2 \%$ to $0.7 \%$ (RH, 2013b), still there exist considerable economic and social impact of fisheries. Fisheries provide an important input for fish processing industry where value added is created. Furthermore, fishing represents very important traditional activity of costal, and in particular of island, population, and it is well known that Croatia is characterized by very long coasts and more than 1000 islands. Thus, fishing represents a substantial economic and social activity for vulnerable island population. Furthermore, fresh fish in important input in the tourism sector which is one of the rare progressive economic sectors in Croatia. Therefore, there is a need for economic analyses of the fishery sector. Lack of data often represents a 
barrier for such a kind of research. This paper partly intends to address such a gap by presenting in a systematic way available indicators about the economic aspects of fishery activities in Croatia.

Since Fishery sector is above average in terms of export-import balance, it is necessary to explore the actual importance of such a trade. Thus, this paper evaluated the assumption that Italy is a significant Croatian marine fishery products trading partner. Due to the closeness of Italy, it is expected that this country represents an important trading partner for fishery products. Since, market conditions determine the price formation and distribution of surplus, in order to obtain better understanding of fishery development in Croatia, it is necessary to explore its exchange of fish products with Italy.

Gallegati et al. (2011) and Vignes and Etienne (2011) analyzed advanced forms of whole sale fish trading. Highly structured whole-sale market trading nowadays represents a common way of market exchange of fishery product. Although several whole sale fish markets initiated to work in Croatia, todays they are mostly closed. Nonfunctioning of the wholesale market for fish is a consequence of problems with fish trading in Croatia. Since Croatian GDP shows negative or slightly positive trends, improvement in any segment of the economy has to be taken with particular attention. Fish trade in Croatia needs significant improvements.

Trade of unobservable goods may be limited due to the problem of information asymmetry. Marine fishery products in this case are in particular exposed to such a problem. Firstly, marine fishery resources are perishable goods dramatically affected by fishing and storage conditions. Secondly, as this is an export oriented industry, the lack of information about product origins, and producer may deter final consumers from buying such a kind of products. This may cause an absence of trade. Certificates are tools sometimes used to reduce information asymmetry problems (OECD, 2011).

Short overview of databases used to obtain data on the fishery sector and trade balance with Italy is presented in the following section. Caches and production of sea fish in Croatia is analyzed in the third section. Trade balance between with Italy and fishing fleet are presented in the fourth and the fifth section respectively. The paper concludes with the analysis of the fish market and final discussion.

\subsection{Materials and methods}

In order to obtain an insight into fishery sector in Croatia, several databases were overviewed. The main used data source is Croatian Bureau of Statistics (CBS) which annually publishes Statistical Yearbook with basic data on fisheries regularly collected by Directorate of Fisheries of Croatian Ministry of Agriculture (Croatian Bureau of Statistics, 2013a).Traffic of Seaport is an occasional publication of the same institution which was used to analyze the density of fish ships traffic (Croatian Bureau of Statistics, 2011). Finally, CBS also publish annual data on export and import at 4-digit customs tariff which was used to study the trade balance of fishery products between Croatia and Italy (Croatian Bureau of Statistics, 2014). EUROSTAT (2014) data were used to compare total catches of Italy and Croatia. Croatian financial agency FINA (2014) dataset was used to obtain more insight in the size of fishery and fish processing business sector. Remaining data was collected from National Strategic Plan for Marine Development of Fisheries of the Republic of Croatia (Republic of Croatia [RH], 2013b) and Marine fishery act (2013a).

\subsection{Catches and production of sea fish in Croatia}

In this section, we analyze structure and volume of fish and other marine commercial catches. The presentation is based on CBS and EUROSTAT data on fisheries. Lokar and Mason (2006) analyze Croatian fishing sector in less recent period.

The importance and share of marine fishery catches and production in Croatia can be seen in Table 1. Total fishery production in 2012 is slightly lower than 52 million Euro where majority of these amounts belongs to finfish. Production of freshwater and diadromous fishes is less than the tonne, which can be neglected when compared to marine fishery production since freshwater and diadromous fishes take less than $500 \mathrm{~kg}$, both in 2011 and 2012. Thus, marine fishery production dominates in Croatian fishery production which is the expected state of a Country such a long coast.

Value and volume of all subcategories of fish production has decreased in 2012 compared to 2011. Since value per tonne has also decreased, one can conclude that a fall in value was sharper than a fall in volume.

\begin{tabular}{|c|c|c|c|c|c|c|}
\hline \multicolumn{7}{|c|}{ Table 01: Value and volume of fish production in Croatia } \\
\hline & \multicolumn{3}{|c|}{ Value in Euro } & \multirow{2}{*}{$\begin{array}{r}\text { Tonnes } \\
2012\end{array}$} & \multicolumn{2}{|c|}{ Euro/Tonne } \\
\hline & 2011 & 2012 & 2011 & & 2011 & 2012 \\
\hline Total fishery products & 80.968 .877 & 51.650 .680 & 69.701 & 62.349 & 1.162 & 828 \\
\hline
\end{tabular}




Finfish and invertebrates
Freshwater and diadromous fishes
Crustaceans and molluscs
Finfish

$\begin{array}{rrrrrr}80.937 .771 & 51.631 .903 & 69.701 & 62.349 & 1.162 & 828 \\ 9.445 & 3.701 & 0,4 & 0,39 & 23.612 & 9.489 \\ 10.460 .041 & 8.472 .378 & 1.635 & 1.782 & 6.398 & 4.754 \\ 70.477 .729 & 43.159 .525 & 68.026 & 60.540 & 1.036 & 713\end{array}$

Source: EUROSTAT

Since freshwater and diadromous fish takes a small portion of total fish catches in Croatia the remaining analysis focuses on marine fishery catches and production.

Catch and production of sea fish and other marine species is presented in Figure 1 and Table 2. It needs to be mentioned that there is anecdotal evidence that unregistered marine fish catch in Croatia is rather large. Government subsidies and other policy instruments significantly affect the decision of fishermen to register their catches.

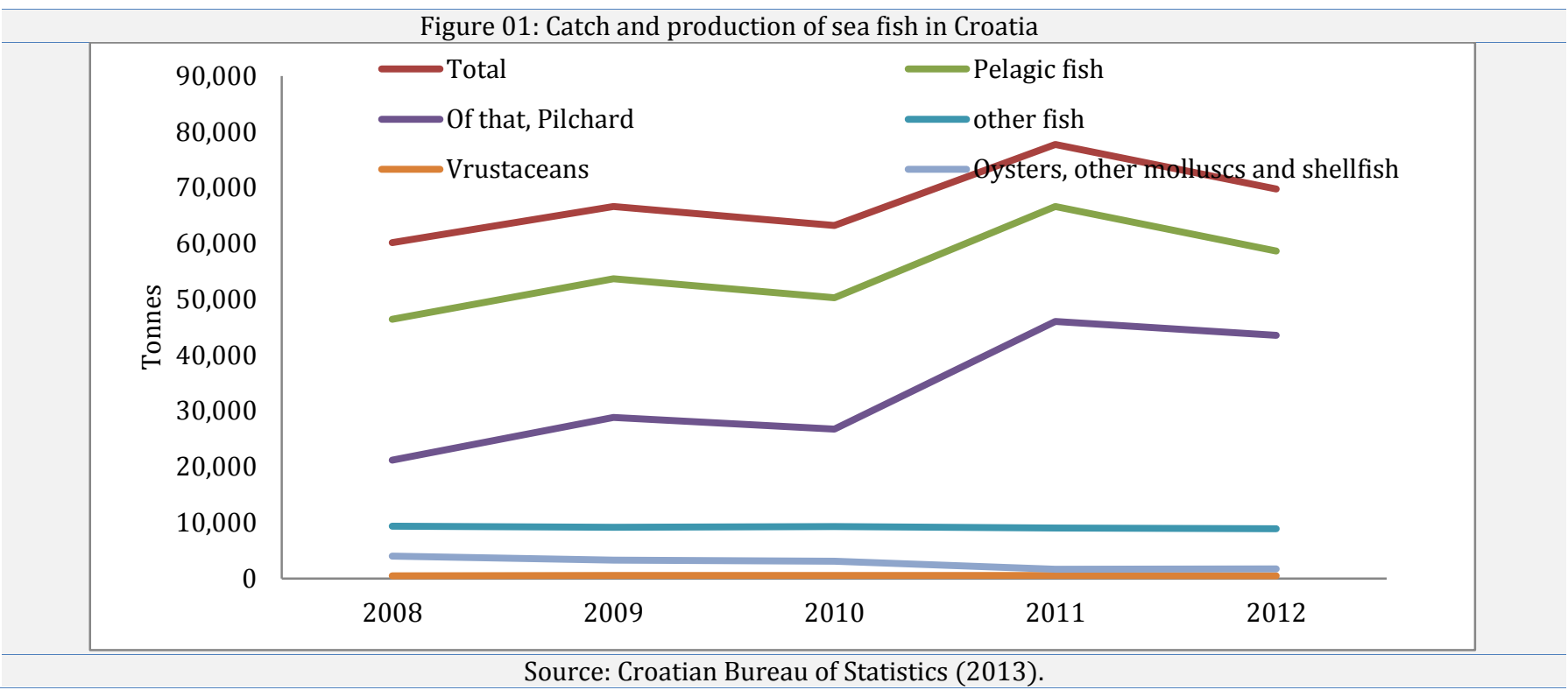

Catch structure is presented in Table 3 where it can be seen that in 2012 pelagic fish participates with more that $84 \%$ in total volume of fish catch. Species which dominates, as in pelagic fish catch, so in total fish catch, is Pilchard with $62.4 \%$ in total fish catch and production. The remaining catch mostly belongs to demersal fish. Share of crustaceans in total catch volume is less than $1 \%$ during the whole period.

Table 02: Catches and production of sea fish, crustaceans and other molluscs and shellfish in Croatia (in Tonnes)

\begin{tabular}{|c|c|c|c|c|c|c|}
\hline \multirow{2}{*}{ Year } & \multirow{2}{*}{$\begin{array}{l}\text { Total fish catch and } \\
\text { production in } \\
\text { Tonnes }\end{array}$} & \multicolumn{2}{|c|}{ Pelagic fish } & \multirow{2}{*}{$\begin{array}{l}\text { Other } \\
\text { fish }\end{array}$} & \multirow{2}{*}{ Crustaceans } & \multirow{2}{*}{$\begin{array}{l}\text { Oysters, other molluscs } \\
\text { and shellfish }\end{array}$} \\
\hline & & Total & Pilchard & & & \\
\hline 2008 & 60.187 & 46.399 & 21.194 & 9.331 & 461 & 3.996 \\
\hline 2009 & 66.619 & 53.659 & 28.815 & 9.137 & 529 & 3.294 \\
\hline 2010 & 63.252 & 50.303 & 26.749 & 9.298 & 543 & 3.108 \\
\hline 2011 & 77.759 & 66.618 & 46.051 & 9.026 & 505 & 1.610 \\
\hline 2012 & 69.748 & 58.687 & 43.527 & 8.894 & 487 & 1.680 \\
\hline
\end{tabular}

Source: CBS, Statistical Yearbook, 2013

Time trends in fish catch and production can be seen in Table 4 which contains annual relative changes in catch volume. It can be noticed that total catch volume increased almost by quarter in 2011 compared to 2010 . This increase owes to a vast increase in pelagic fish catch in 2011 by $32 \%$ compared to 2010, while catch or production of other marine organisms records negative indices in 2011 compared to 2010. In 2012 compared to 2011, all fish catch categories register negative trends, except oysters and other molluscs and shellfish which can be explained by an increase in mariculture.

Table 03: Structure of total fish catch

\begin{tabular}{|c|c|c|c|c|}
\hline \multicolumn{5}{|c|}{ Table 03: Structure of total fish catch } \\
\hline Year & Pelagic fish & Other fish & Crustaceans & Oysers, other mollusc and shellfish \\
\hline
\end{tabular}




\begin{tabular}{|c|c|c|c|c|c|}
\hline 2008 & $77,1 \%$ & $15,5 \%$ & $0,8 \%$ & & $6,6 \%$ \\
\hline 2009 & $80,5 \%$ & $13,7 \%$ & $0,8 \%$ & & $4,9 \%$ \\
\hline 2010 & $79,5 \%$ & $14,7 \%$ & $0,9 \%$ & & $4,9 \%$ \\
\hline 2011 & $85,7 \%$ & $11,6 \%$ & $0,6 \%$ & & $2,1 \%$ \\
\hline 2012 & $84,1 \%$ & $12,8 \%$ & $0,7 \%$ & & $2,4 \%$ \\
\hline \multicolumn{6}{|c|}{ Source of Data: Croatian Bureau of Statistics, Statistical Yearbook, 2013} \\
\hline \multicolumn{6}{|c|}{ Table 04: Chain indices of fish catch } \\
\hline Year & $\begin{array}{l}\text { Total fish catch } \\
\text { and production }\end{array}$ & $\begin{array}{l}\text { Pelagic } \\
\text { fish }\end{array}$ & $\begin{array}{l}\text { Other } \\
\text { fish }\end{array}$ & Crustaceans & $\begin{array}{l}\text { Oysters, other mollusc and } \\
\text { shellfish }\end{array}$ \\
\hline $2009 / 2008$ & $11 \%$ & $16 \%$ & $-2 \%$ & $15 \%$ & $-18 \%$ \\
\hline $2010 / 2009$ & $-5 \%$ & $-6 \%$ & $2 \%$ & $3 \%$ & $-6 \%$ \\
\hline $2011 / 2010$ & $23 \%$ & $32 \%$ & $-3 \%$ & $-7 \%$ & $-48 \%$ \\
\hline $2012 / 2011$ & $-10 \%$ & $-12 \%$ & $-1 \%$ & $-4 \%$ & $4 \%$ \\
\hline
\end{tabular}

Value of purchased through first sale is presented in Table 5. Data on the value follow trends detected by analysis of catch volume, so that value of purchased fish decreased in 2012 compared to 2011. When the time trend in catch volume and value are compared, it can be noticed that a decrease in total fish catch volume coincides with a decrease in the volume of fish purchased through the first sale.

\begin{tabular}{ccccc}
\hline \multicolumn{4}{c}{ Table 05: Value of purchased and sold fishing (includes river fish) } \\
\hline \multirow{2}{*}{ Year } & \multicolumn{3}{c}{ Fish, fresh or cooled } & $\begin{array}{c}\text { Crustaceans (not frozen), other water } \\
\text { invertebrates }\end{array}$ \\
\cline { 2 - 5 } & $000 \mathrm{HRK}$ & $\%$ & $000 \mathrm{HRK}$ & $\%$ \\
\hline 2008 & 379.914 & 97,16 & 11.089 & 2,84 \\
2009 & 328.711 & 97,13 & 9.698 & 2,87 \\
2010 & 277.278 & 99,55 & 1.240 & 0,45 \\
2011 & 311.689 & 98,77 & 3.874 & 1,23 \\
2012 & 302.029 & 99,06 & 2.874 & 0,94 \\
\hline
\end{tabular}

Subsequently fishery product trade between Italy and Croatia is analyzed and in light of the recent Croatian accession to the EU. Table 6 compares the EU, Italian and Croatian volume of catch in Mediterranean within period 2008-2012. These values contain only the caches within Mediterranean, so that they refer mostly to south European countries. It can be noticed that Italy participates in almost half of the EU catch in Mediterranean. While in 2008 Croatian catch is around $10 \%$ of the EU catch, in 2011 it represented one-sixth of the EU catch. Even in the northern and middle Adriatic Sea Croatian share in total catches is 30\% (UNDP, 2012).

\begin{tabular}{lccccc}
\hline \multicolumn{5}{c}{ Table 06: Catches in Mediterranean in tonnes live weight } \\
\hline GEO/TIME & 2008 & 2009 & 2010 & 2011 & 2012 \\
\hline $\begin{array}{l}\text { European Union (27 } \\
\text { countries) }\end{array}$ & 446.387 & 456.105 & 429.094 & 404.204 & \\
Croatia & 49.011 & 55.365 & 52.397 & 70.534 & 63.599 \\
Italy & 221.652 & 239.564 & 228.211 & 210.591 & 195.839 \\
\hline & \multicolumn{5}{c}{ Source: EUROSTAT } \\
\hline
\end{tabular}

It can be noticed in Table 6 that Italian catch in 2012 was 3 times larger than Croatian catch. However, it can be seen in Figure 2 that Croatian catch demonstrates continuous growth and the Italian catch demonstrate continuous fall. Such trends can partly be a reason for a significant fish export from Croatia to Italy. Since Italian catches shrink, a shortage of domestic fish supply in Italy is compensated by import. 


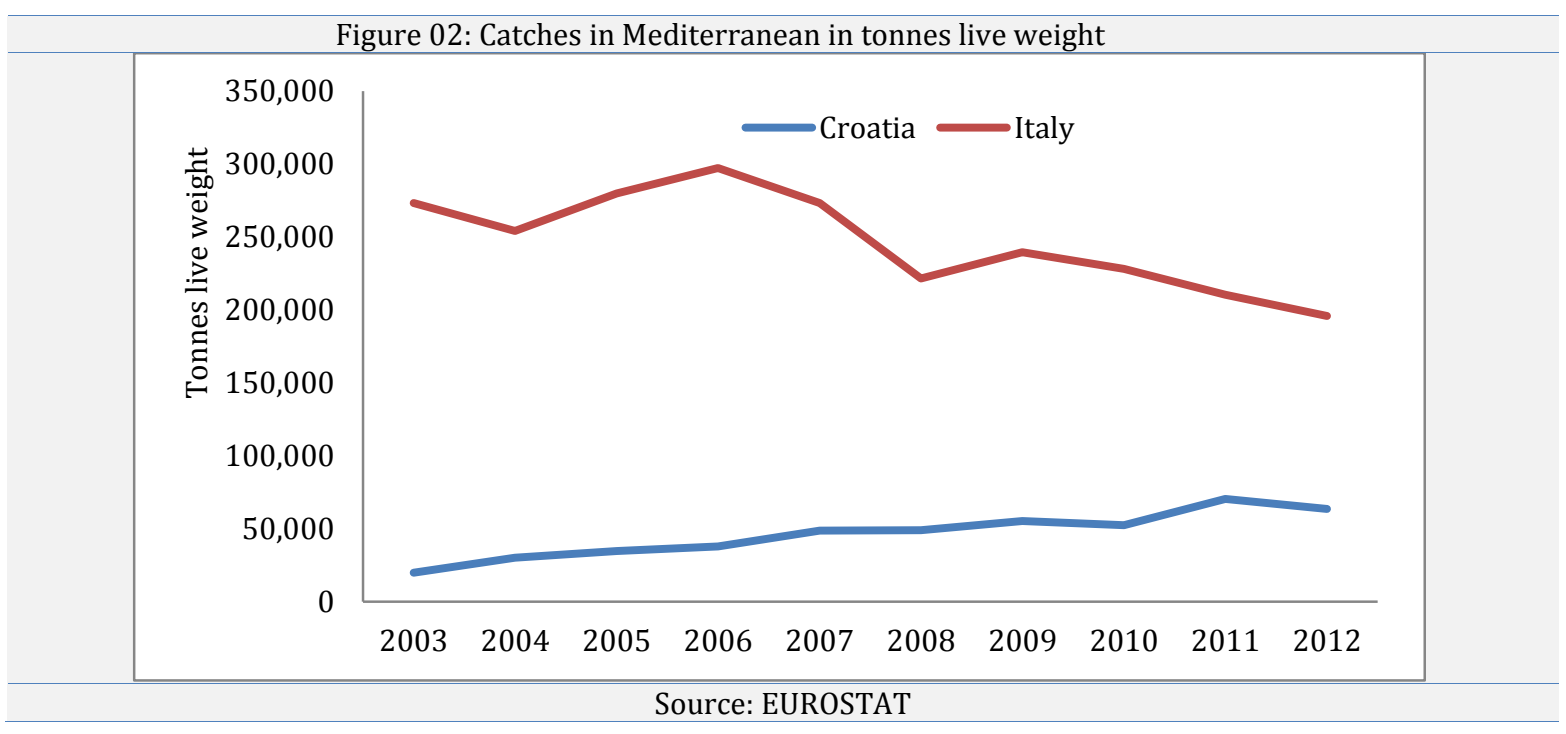

When aquaculture activities are compared, ratios are slightly different. Volume of fish production from aquaculture in Italy is almost 10 times larger than in Croatia. In fact, mariculture in Croatia is far from sufficiently developed. There are large capacities for mariculture development along Croatian Adriatic coast. However, due to incompatibility with tourism activities and due to negative environmental impacts, mariculture sector remains relatively small.

Table 07: Production from aquaculture excluding hatcheries and nurseries in tonnes live weight

\begin{tabular}{lrrrrr}
\hline Country/Year & 2008 & 2009 & 2010 & 2011 & 2012 \\
\hline Croatia & 16.387 & 16.329 & 15.686 & 17.189 & 13.921 \\
Italy & 157.865 & 162.325 & 153.626 & 164.127 & - \\
\hline \multicolumn{5}{c}{ Source of Data: EUROSTAT } \\
\hline
\end{tabular}

\subsection{Trade balance between Croatia and Italy}

Fishing is a recognised exporting sector in Croatia where there is a trend to export expensive fishery products and to import cheap ones (EUMOFA, 2013). Since one of the aims of this paper is to obtain an insight into the relation between Croatia and Italy within the fishery sector, the data on quantity and value of various fishery products are presented in Table 11. More fish products are exported from Croatia to Italy than imported from Italy to Croatia, with the exception of fresh fillets.

Table 11. The classification of products is based on customs tariff level 4.

\begin{tabular}{|c|c|c|c|c|c|c|c|}
\hline \multirow{2}{*}{ Product } & \multirow{2}{*}{ Export/Import } & \multicolumn{2}{|c|}{2010} & \multicolumn{2}{|c|}{2011} & \multicolumn{2}{|c|}{2012} \\
\hline & & Tons & 000 euro & Tons & 000 euro & Tons & 000 euro \\
\hline \multirow{2}{*}{ Live fish } & Export & 288 & 419 & 423 & 568 & 286 & 427 \\
\hline & Import & 25 & 1.489 & 36 & 1.684 & 31 & 1.515 \\
\hline \multirow{2}{*}{$\begin{array}{l}\text { Fresh or } \\
\text { chilled }\end{array}$} & Export & 10.189 & 20.165 & 11.701 & 25.652 & 10.224 & 23.026 \\
\hline & Import & 144 & 711 & 188 & 548 & 166 & 494 \\
\hline \multirow{2}{*}{ Frozen } & Export & 529 & 440 & 1.855 & 1.625 & 1.392 & 1.309 \\
\hline & Import & 76 & 293 & 86 & 290 & 33 & 168 \\
\hline \multirow{2}{*}{ Fish fillets } & Export & 21 & 68 & 18 & 58 & 40 & 172 \\
\hline & Import & 41 & 178 & 60 & 301 & 56 & 317 \\
\hline \multirow{2}{*}{$\begin{array}{l}\text { Dried/ } \\
\text { salted }\end{array}$} & Export & 6.172 & 13.763 & 5.909 & 12.847 & 2.152 & 5.467 \\
\hline & Import & 36 & 145 & 24 & 90 & 33 & 166 \\
\hline \multirow{2}{*}{$\begin{array}{l}\text { Crusta- } \\
\text { ceans }\end{array}$} & Export & 61 & 930 & 68 & 1.123 & 60 & 999 \\
\hline & Import & 86 & 602 & 127 & 985 & 117 & 923 \\
\hline \multirow{2}{*}{ Molluscs } & Export & 534 & 1.765 & 564 & 2.444 & 634 & 2.516 \\
\hline & Import & 267 & 836 & 206 & 724 & 179 & 609 \\
\hline
\end{tabular}

\subsection{Marine vessels and fishing craft}

Important aspects of the EU common fishery policy are member quotas in terms of fish fleet capacity which affects the catch volume and value. Table 8 provides data on the size of Croatian fishing fleet and tools. 
Table 08: Marine vessels and fishing craft

\begin{tabular}{|c|c|c|c|c|c|c|}
\hline & \multirow[b]{2}{*}{$\begin{array}{l}\text { Ships } \\
\text { Number }\end{array}$} & \multirow[b]{2}{*}{$\begin{array}{l}\text { Total size of } \\
\text { vessels, GT }\end{array}$} & \multicolumn{2}{|c|}{ Fishing nets by type } & \multirow[b]{2}{*}{ Drift nets } & \multirow[b]{2}{*}{ Single and triple gillnets* } \\
\hline & & & Trawl nets & $\begin{array}{l}\text { Purse seine } \\
\text { nets }\end{array}$ & & \\
\hline 2008 & 488 & 28.984 & 1.910 & 892 & 1.118 & 17.752 .600 \\
\hline 2009 & 445 & 31.236 & 1.850 & 841 & 1.011 & 17.630 .200 \\
\hline 2010 & 477 & 32.643 & 1.254 & 709 & 803 & 15.330 .000 \\
\hline 2011 & 420 & 32.300 & 1.254 & 842 & 756 & 12.028 \\
\hline 2012 & 424 & 32.922 & 1.130 & 836 & 750 & 7.015 \\
\hline
\end{tabular}

Source of Data: Croatian Bureau of Statistics, Traffic of Seaports, 2011;

*From 2011 Gillnets were presented in numbers while till 2010, they were measured in metres

Contrary to the trends in catch and production of sea fish, the trends in fishing fleet indicate that the number of vessels has increased recently, as well as total size of vessels measured in gross tonnage (GT) which is a measure unit for the overall size of a ship which is grounded in the International Convention on Tonnage Measurement of Ships (1969). However, total size of vessels decreased in 2012 compared to 2008. The EU Common Fishery policy certainly affected the trends in Croatian fishing fleet since it size is taken into account in the determination of national quotas. The data on fishing tools indicate that single and triple gillnets dominate by number.

In order to obtain closer insight into the level of equipment across vessels, the average size of vessels in GT, and the average number or fishing nets per vessels is presented in Table 9. The equipment intensity of vessels seems rather stable. An average vessel is equipped by 3 trawl nets, 2 purse seine nets, 2 drift nets and 17 gillnets. A slight increase in average vessel size in terms of GT is noticed in 2012 compared to 2011. Such a trend is not surprising knowing that Croatian fishing ships are rather small compared to the EU averages and represented mostly by small-scale coastal fisheries (EUMOFA, 2013)

Table 9: Average size of vessel in GT, the average number of nets by vessel

\begin{tabular}{|c|c|c|c|c|c|}
\hline & \multirow{2}{*}{$\begin{array}{l}\text { Average size of } \\
\text { vessels, GT }\end{array}$} & \multicolumn{2}{|c|}{ Fishing nets by type } & \multirow{2}{*}{ Drift nets } & \multirow{2}{*}{ Single and triple gillnets } \\
\hline & & Trawl nets & Purse seine nets & & \\
\hline 2008 & 59 & 4 & 2 & 2 & 36378 \\
\hline 2009 & 70 & 4 & 2 & 2 & 39618 \\
\hline 2010 & 68 & 3 & 1 & 2 & 32138 \\
\hline 2011 & 77 & 3 & 2 & 2 & 29 \\
\hline 2012 & 78 & 3 & 2 & 2 & 17 \\
\hline
\end{tabular}

Arrivals of fishing ships by ports are also analyzed. According to CBS (2011) in 2010, out of the total quantities of goods in the international traffic (8,321 thousand tonnes) loaded in the seaports of the Republic of Croatia, the most of them departed towards ports of Italy (52.4\%).

The following table presents traffic in arrivals of fishing ships in Adriatic statistical ports where. Fishing ships include fish catching and fish processing vessels, while a statistical port is composed of one or more ports, controlled by a single port authority.

\begin{tabular}{|c|c|c|c|c|c|}
\hline & & & & & \\
\hline & 2000 & 2007 & 2000 & 2007 & 2010 \\
\hline Number of vessels & 619 & 496 & 951 & 1011 & 1069 \\
\hline Thousands of GT & 85 & 68 & 74 & 86 & 98 \\
\hline Average size of vessel in GT & 137 & 137 & 78 & 85 & 92 \\
\hline $\begin{array}{l}\text { Share of North Adriatic (in } \\
\text { number of vessels) }\end{array}$ & 65 & 76 & 80 & 71 & 71 \\
\hline $\begin{array}{l}\text { Share of North Adriatic (in } \\
\text { thousands of GT) }\end{array}$ & 75 & 82 & 64 & 55 & 64 \\
\hline
\end{tabular}

There is an increasing trend in fish ship arrivals, both in number of vessels and GT. The most of arrivals happen in statistical ports of northern Adriatic (Counties: Istria, Primorjei Gorski Kotar, and Lika-Senj). Previously, this share was even larger in terms of GT till 2008 when the trends reversed. From comparison of arrived fishing vessel size in GT in Table 9 to the vessels in Croatian fishing fleet in Table 8 it can be noticed that significantly larger fishing vessels arrive to the statistical ports than vessels contained in Croatian fishing fleet.

\subsection{Fish market}


In terms NACE classification of activities, the main economic activities related to marine fishing are contained in classes: 03.11 (marine fishing), 03.21 (marine aquaculture) and 10.20 (processing and preserving of fish, crustaceans and molluscs), 46.38 (wholesale of other food, including fish, crustaceans and molluscs) and 47.23 (retail sale of fish, crustaceans and molluscs in specialized stores). In 2013, there were 18, 10, 3, 15 and 1 registered firms in mentioned classes respectively, according to the database of FINA (Financial Agency), a leading Croatian company for financial mediation. Those are firms which are obliged to submit annual financial statement to FINA and which main activity is one of the listed above. These data exclude fishing cooperatives and crafts. All mention firms (47 in total) are small ones except one medium-size firm (FINA, 2014).

Thus, fish processing sector is relatively small in Croatia. Traditionally, most of the industry was based on canning, where small pelagic fish was used as a raw material. In a recent period, share of salted fish and frozen fish production has been increasing. Most of the demersal special catch is distributed to the final consumers as fresh that is, it is not used for processing (Republic of Croatia [RH], 2013b). There are 18 fishing cooperatives approved by Directorate of Fisheries of Croatian Ministry of Agriculture with total number of 443 members where some of the fisheries signal the capacities to become producer organizations (Republic of Croatia [RH], 2013b).

Since the wholesale marketplaces are established with difficulties in Croatia (the largest wholesale fish market in Rijeka had bankrupted), the trade channels of the marine fishery products are rather heterogeneous. For example, a significant share of the catches has been sold directly to the restaurants. Thus, as we previously, mentioned. Most of the small pelagic fish is used as input for the fish processing industry or as a feed for tunas. Demersal catches are directed to the restaurants and market-places for the final consumption as fresh, or they are exported after the first sale.

Bush (2004) analyzed the importance of fish trading networks. Thus, we mention here the main players of marine fish distribution network in Croatia. Beside professional fishermen, there exists a category of small-scale fishermen in Croatia, which is not in line with the EU legislation, and thus, it is going to be abolished. Fishermen are, usually, organized into fishermen cooperatives (Republic of Croatia [RH], 2010) whose basic activity by NCA is fishing or aquaculture. Their aims are: common and organized access to the market, sustainable fishing, and production planning and adjustment to demand. Members of fishing cooperatives have to sell 80\% of their catch through cooperatives. First sale can be done to registered buyers only. First buyers are legal or physical persons who are registered at the register of first buyers (Republic of Croatia [RH], 2013a). Other players who determine the price and other trading conditions are processing companies, exporters, supermarkets, wholesale markets, big retail chains, fish market-places and final consumers.

The first contact of fish with mainland happens on the landing site. That is a part of the port area, or exceptionally another place outside of port areas, used to unload fish and other marine organisms or other products resulting from commercial marine fishing. Next, the fish is directed to buy off sites, selected objects in line with relevant food regulation serving for the first fish and other marine resources fish sale to the first retail or wholesale buyer. The is a lack of necessary infrastructure which significantly determines market conditions, such as fishing ports, buy off stations and whole sale markets. The lack of storage and cooling capacities limit the capacities of fishermen to adjust to demand. On the side of demand, lack of information is evident, so that one of the aims of National strategy plan for development of fisheries of the Republic of Croatia is improvement in transparency of the market for fish (RH, 2013b) which would improve fishermen market position (European Commission D.G. Maritime Affairs and Fisheries, 2013). Consumption of fish in Croatia is rather low taking into consideration that that Croatia is a country with very long coast. Lack of trust is one of the reasons for such a low level of consumption. The importance of consumer trust for the fishery sector is discussed in Pieniak et al. (2007).

\subsection{Results and discussion}

We find that pelagic fish dominates in total fish catch in Croatia, which share demonstrated a dramatic increase in 2011. Crustaceans and other invertebrates participate with less than $1 \%$ of total first sale value in 2012.

Time trends of total catch volume and of first sale value surprisingly coincide. Such a finding opposes to what is expected based economic law of demand, due to which a decrease in supply, ceteris paribus, increases the equilibrium market price. Since this analysis is based on an aggregate date, further investigation would be needed in order to infer about the actual causes which drive the trends identified. A decrease in total fish catch volume and value can be an indicator of a serious problem with marine biodiversity so that fish catch deters both in quantity and quality.

Croatian catch in the Mediterranean Sea is about $10 \%$ of the Italian catch in the same geographical zone. However, it has been increasing while Italian catch in the same zone has been decreasing so that the gap between Italian and Croatian catches shrinks. Furthermore, it can be concluded that more fish is exported from Croatian to Italy than it has been imported from Italy to Croatia. Dominant exporting category is fresh or chilled fish. Exported and imported values and volumes of most fish product categories increase from 2010 to 2011 and decrease from 2011 to 2012. 
However, import of fish fillets varies in the opposite direction, and it firstly decreases and then increases. The value of imported fish fillets constantly increases. Such trends follow the crises, both in Italy and Croatia, so that one may consider the possibility that fish fillet is an inferior good which demand increases with a decrease in income. Furthermore, fish fillets are processed type of fish product which indicates that there is a lack of fish processing companies in Croatia. Molluscs export demonstrates continuous increase, while molluscs import demonstrates continuous decrease which may indicate a better supply from domestic sources such as mariculture.

Average size of Croatian fishing fleet vessel is much lower than the average fishing vessel size arriving at Croatian ports. Although both number and size of fishing vessels has increased from 2008 to 2011, still the Croatian fishing fleet has been composed mostly of small-scale coastal fisheries. Since the EU common fishery policy restricts the size of the fishing fleet, it is questionable if the Croatian fishing fleet may enlarge in the future. Market trade is underdeveloped since whole sale markets do not function. Croatian fish processing industry consists of small firms, while the fishermen are organized into fishing cooperatives through which they sell most of their catch. Underdeveloped infrastructure, such as fishing ports, buy off stations and whole sale markets, significantly affect the market conditions, so that becomes expensive and difficult to place the catch to the international market. Thus, an important part of the catch is sold directly to restaurants and final consumers. Rather small number of firms whose main registered activity is related to fishing or fish processing indicates that the size of this sector is rather small.

\subsection{Conclusions and policy implications}

Volume and value of fish catch in Croatia has decreased. This can be caused by serious deterioration of marine biodiversity. More intense fishery monitoring programs could prevent further losses in marine biodiversity which in turn is crucial for the development of the fishery sector.

Dominance of pelagic fish in total catches in Croatia (i.e. pilchard) indicate that there should be a good input supply for growing mariculture, since such a fish represents a feed for tunas and other types of cultivated fish. Croatian fish market is underdeveloped, and Italy is an important Croatian fish trading partner as confirmed by large exports of fish products from Croatia to Italy. The exports might even increase in the future since it is evident that the Italian catches in the Mediterranean shrink. However, most of the exported fish is fresh or chilled.

Thus, small capacities of Croatian fishing fleet as well as domination of small firms of the fishery sector indicate that the creation of additional value is needed along the fish market trade network. Good functioning of wholesale fish markets, additional storage and cooling capacities, as well as additional information provision about quality through certification, can assure creation of additional value along the chain. In other words, by resolving problems of adverse selection and moral hazard, certification schemes may restore the market and foster the trade. Furthermore, certification may affect the structure of the goods exchanged, so that quality, environmental and social impact of fishing techniques and processes are taken into account.

\section{References}

Bush, R.S., 2004. Scales and sales: Changing social and spatial fish trading networks in the Siiphandone Fishery-Lao PDR, Singapore. Journal of tropical Geography, 25(1): 32-50. http://dx.doi.org/10.1111/j.01297619.2004.00171.x

Croatian Bureau of Statistics, 2014. Export/Import, by headings of Customs Tariff (CT 4) and countries of destination/origin". Zagreb: CBS Publication. Retrieved from http://www.dzs.hr/default_e.htm.

Croatian Bureau of Statistics, 2013. Statistical Yearbook. Zagreb: CBS Publication. Retrieved from http://www.dzs.hr/default_e.htm.

Croatian Bureau of Statistics, 2011. Traffic in seaports 2006-2010. Zagreb: CBS Publication. Retrieved from http://www.dzs.hr/Hrv_Eng/Other/morske-luke_2006-2010.pdf.

European Commission D.G. Maritime Affairs and Fisheries., 2013. Common market organization: Knowing the market better to boost earnings, Fisheries and Aquaculture in Europe (European Commission D.G. Maritime Affairs and Fisheries Report no. 61, May 2013). Bruxelles: European Commission D.G. Maritime Affairs and Fisheries. Retrieved from http://ec.europa.eu/fisheries/documentation/magazine/mag61_en.pdf.

EUMOFA. (2013.). Monthly highlights. July. Bruxelles: European Commission D.G. Maritime Affairs and Fisheries. Retrieved from: http://ec.europa.eu/fisheries/market-observatory/documents/10157/1a08a9d7-9f01-4500-b194f45bd31b64c8

EUROSTAT. (2014). Catches - Italy and Croatia fishing areas. Available from Eurostat database. Retrieved from http://epp.eurostat.ec.europa.eu/portal/page/portal/statistics/search_database.

Financial Agency [FINA]., 2014. The size of fishery and fish processing business sector [statistics]. Available from FINA Data database http://www.fina.hr/Default.aspx?sec=1135. 
Gallegati, M., Giulioni, G., Kirman, A., \&Palestrini, A., 2011. What's that got to do with the price of fish? Buyers behavior on the Ancona fish market. Journal of Economic Behavior and Organization, 80: 20-33, http://dx.doi.org/10.1016/j.jebo.2011.01.011

Lokar, A.L., \& Mason, M.C., 2006. A Market overview of the fishing sector in Croatia. Transition Studies Review, 13(3): 589-604. http://dx.doi.org/10.1007/s11300-006-0128-6

OECD. (2011). Fisheries and Aquaculture Certification, OECD Publishing. doi: 10.1787/9789264119680-en. http://dx.doi.org/10.1787/9789264119680-en

Pieniak, Z., Verbeke, W., Scholderer, J., Brunso, K., \& Olsen, S.0., 2007. European Consumers' use of and trust in information sources about fish. Food Quality and Preference, 18: 1050-1063. http://dx.doi.org/10.1016/j.foodqual.2007.05.001Republic of Croatia [RH]. (2013a). Marine Fishery Act, in NN $81 / 13$, Zagreb

Republic of Croatia [RH]. (2013b). National Strategic Plan of Development of Fisheries. Retrieved from: http://www.mps.hr/ribarstvo/UserDocsImages/NSP/NSP_OP_06112013/15110P_NSP_ENG/National\%20strat egic\%20plan\%20for\%20development\%20of\%20fisheries\%20of\%20the\%20Republic\%20of\%20Croatia.pdf.

Republic of Croatia [RH]., 2010. Ordinance on fishing cooperatives, in NN 48/10, Zagreb

UNDP. (2012). Croatian Marine Fishery: State and Perspectives, UNDP Project Coast, ZagrebVignes, A., \& Etienne, J.M., 2011. Price formation on the Marseille fish market: Evidence from a network analysis. Journal of Economic Behavior and Organization, 80: 50-67. 